\title{
EFFECT OF A SIMULATED HEAT WAVE IN THERMAL AND AERIAL
} ENVIRONMENT BROILER-REARING ENVIRONMENT

Doi:http://dx.doi.org/10.1590/1809-4430-Eng.Agric.v36n2p 271-280/2016

\section{MARCOS M. DO VALE ${ }^{1}$, DANIELLA J. DE MOURA ${ }^{2}$, IRENILZA DE A. NÄÄS ${ }^{3}$, THAYLA M. R. C. CURI ${ }^{4}$, KARLA A. O. LIMA ${ }^{5}$}

\begin{abstract}
Global warming increases the occurrence of events such as extreme heat waves. Research on thermal and air conditions affecting broiler-rearing environment are important to evaluate the animal welfare under extreme heat aiming mitigation measures. This study aimed at evaluating the effect of a simulated heat wave, in a climatic chamber, on the thermal and air environment of 42-day-old broilers. One hundred and sixty broilers were housed and reared for 42 days in a climatic chamber; the animals were divided into eight pens. Heat wave simulation was performed on the $42^{\text {nd }}$ day, the period of great impact and data sampling. The analyzed variables were room and litter temperatures, relative humidity, concentrations of oxygen, carbon monoxide and ammonia at each pen. These variables were assessed each two hours, starting at 8 am, simulating a day heating up to $4 \mathrm{pm}$, when it is reached the maximum temperature. By the results, we concluded that increasing room temperatures promoted a proportional raise in litter temperatures, contributing to ammonia volatilization. In addition, oxygen concentrations decreased with increasing temperatures; and the carbon monoxide was only observed at temperatures above $27.0{ }^{\circ} \mathrm{C}$, relative humidity higher than $88.4 \%$ and litter temperatures superior to $30.3{ }^{\circ} \mathrm{C}$.
\end{abstract}

KEYWORDS : ammonia, gas production, animal welfare, oxygen, litter temperature

\section{ONDA DE CALOR SIMULADA E SEU IMPACTO NO AMBIENTE TÉRMICO E AÉREO DE FRANGOS DE CORTE}

RESUMO: O aquecimento global aumenta a ocorrência de eventos extremos como as ondas de calor. Pesquisas sobre como as condições térmicas e aéreas afetam o ambiente de produção de frangos de corte são importantes para se avaliar o bem-estar animal sob condições extremas de calor, objetivando medidas mitigadoras. Este estudo pretende avaliar o efeito da simulação de ondas de calor em câmara climática, sobre o ambiente térmico e aéreo de frangos de corte com 42 dias de idade. 160 frangos foram alojados e criados, de 1 a 42 dias de idade, em câmara climática que foi dividida em oito baias. A simulação de onda de calor foi realizada no $42^{\circ}$ dia de criação das aves, memento de maior impacto e da coleta dos dados. As variáveis foram coletadas em intervalos de duas horas a partir das 8 horas da manhã, simulando o aquecimento do dia até às 16 horas, horário de máxima, sendo coletados temperatura ambiente, temperatura da cama, umidade relativa do ar, concentrações de oxigênio, monóxido de carbono e amônia em cada baia, nos intervalos de duas em duas horas. Com os resultados obtidos na câmara climática, foi possível concluir que o aumento da temperatura ambiente ocasionou aumento na temperatura da cama, o que, consequentemente, contribuiu para o aumento da volatilização da amônia. A concentração de oxigênio foi reduzida enquanto a temperatura foi aumentada. A presença de monóxido de carbono foi observada quando a temperatura ambiente estava acima de $27,0^{\circ} \mathrm{C}$, a umidade relativa superior a $88,4 \%$ e a temperatura da cama estava superior a $30,3^{\circ} \mathrm{C}$.

PALAVRAS-CHAVE: amônia, bem-estar animal, oxigênio, produção de gás, temperatura da cama de frango.

\footnotetext{
${ }^{1}$ Zootecnista, Prof. Doutor, Departamento de Zootecnia, UFPR/Curitiba - PR, Fone: (41) 3350-5821, marcos.vale@ufpr.br

${ }^{2}$ Eng $^{\circ}$ A grônoma, Profa. Doutora, Departamento de Construções Rurais, UNICAMP/Campinas - SP, daniella.moura@feagri.unicamp.br

${ }^{3}$ Eng $^{\circ}$ Civil, Profa. Doutora, Departamento de Construções Rurais, UNICAMP/Campinas - SP, irenilza@ feagri.unicamp.br

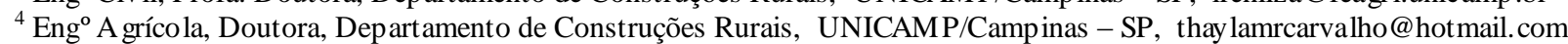

${ }^{5}$ Médica Veterinária, Doutora, Departamento de Construções Rurais, UNICAMP/Campinas - SP, Karla.lima @y mail.com Recebido pelo Conselho Editorial em: 30-9-2015
}

Aprovado pelo Conselho Editorial em: 5-2-2016 


\section{INTRODUCTION}

Thermal and aerial environments are extremely important factors that affect broiler poultry production. Climate change is expected to result in more frequent, more intense, and longer heat waves (HENDERSON et al., 2011; RENAUDEAU et al., 2012; SKUCE et al., 2013; SOSSIDOU et al., 2014). The heat wave can be defined by long, hot summers with higher minimum temperatures and humidity (KENT et al., 2014).

Broiler genetic selection reduces the ability of birds to maintain energy, heat and water balance, leading to lesser capability of overcoming heat stress. Lower values of feed intake, weight gain and viability are observed in thermally stressed broilers, especially under high temperature (BOIAGO et al., 2013; OBA et al., 2012). Temperature, relative humidity and wind speed are the major environmental factors affecting animal thermal comfort, providing limits for adequate production (NASCIMENTO et al., 2011; AMARAL et al., 2011). The high temperature might cause mortality in birds according to their exposure to high temperatures reaching hyperthermia, a high body temperature condition leading to respiratory alkalosis and increasing blood $\mathrm{pH}$ due to excessive panting, causing the death of the birds (JULIAN, 2005; TOYOMIZU et al., 2005; ABIDIN \& KHATOON, 2013). The climate change and heat waves events are responsible for severe production losses in broiler facilities (VALE et al., 2010; NÄ̈̈S et al., 2010).

In addition to the high heat, dust and gas concentration have influence on poultry production and chicken mortality (LE BOUQUIN et al., 2013). Uveitis has been observed at environments with ammonia concentration above $25 \mathrm{ppm}$, while the ideal concentration is below $10 \mathrm{ppm}$ according the broiler management guide developed by COBB-VANTRESS (2013). The increased levels of atmospheric $\mathrm{NH}_{3}$ in poultry houses has been linked to decreased bird performance and immunity, as well as to a higher susceptibility to respiratory infections (GUSTAFSSON et al., 2013; NWAGWU et al., 2012). The hypothesis raised in this study is that heat waves affect thermal and aerial environments of broilers reared in chambers. Therefore, we simulated a heat wave in a broilerrearing chamber and checked the effects on psychometric variables and gas concentration when birds reached 42 days old.

\section{MATERIAL AND METHODS}

The study was carried out at the Thermal Comfort Laboratory II, in the College of Agricultural Engineering of the Universidade de Campinas - UNICAMP (Campinas University). A number of 160 male broilers were reared in a chamber during 42 days in order to simulate the heat wave in the last day before slaughtering.

The test chamber was divided into eight pens using wire meshes set within PVC pipe frames. Each pen had an area of $1.55 \times 1.00 \mathrm{~m}$ and was equipped with individual feeders and drinkers. A 0.15-m layer of wood shavings was used as litter for the chicks, being replaced when moisture was excessive.

Stocking density was of 13.3 birds $\mathrm{m}^{-2}$ (without feeder and drinker), being reared under standard commercial management. Chamber venting was maintained under a wind speed of $73.45 \mathrm{~m}^{3} \mathrm{~h}^{-1}$ to achieve thermal comfort at each age until the $42^{\text {nd }}$ day of rearing.

Heat wave simulation was controlled by a computational software developed by the Research Group on Precision Livestock Farming belonging to the College of Agricultural Engineering at from UNICAMP. Chamber indoor temperature was also adjusted by computational software, raising the temperature every 15 minutes gradually, within a 2-hour interval, starting at 8 am up to 4 pm. This temperature alternation is in accordance with records of the thermal dynamic of heat waves events in broilers houses located in São Paulo, Brazil.

Data of temperature, relative humidity, wind speed, as well as concentrations of ammonia, carbon monoxide and oxygen were measured during the two-hour cycles starting at $8 \mathrm{am}, 10 \mathrm{am}, 12$ $\mathrm{pm}, 2 \mathrm{pm}$ and $4 \mathrm{pm}$. 
We set a datalogger (OnSet Hobo Pendant Temperature, Onset Computer Corporation) to monitor and record the values of dry bulb temperature and relative humidity. Wind speed was quantified with an anemometer (Pacer ${ }^{\circledR}$ HTA 4200). A gas detector (Gas Alert Micro 5 from BW Technologies) measured the concentrations of the gases. All measurements were performed at 0.20 $\mathrm{m}$ height from the litter surface at each pen.

A thermometer collected the litter temperature with a $0.15-\mathrm{m}$ probe Omegascope ${ }^{\circledR}$ (Model 05520 series) placed at $0.05 \mathrm{~m}$ depth in the litter.

The statistical software Minitab ${ }^{\circledR}$ was used to calculate date regression analysis and Pearson correlation. Previously, data normality was tested and no transformations were required, except for carbon dioxide ones that required a binary transformation due to gas-occurrence uncertainty.

\section{RESULTS AND DISCUSSION}

Figure 1 shows that the simulated temperature increased along the day as expected, which is similar to a one-day heat wave event.

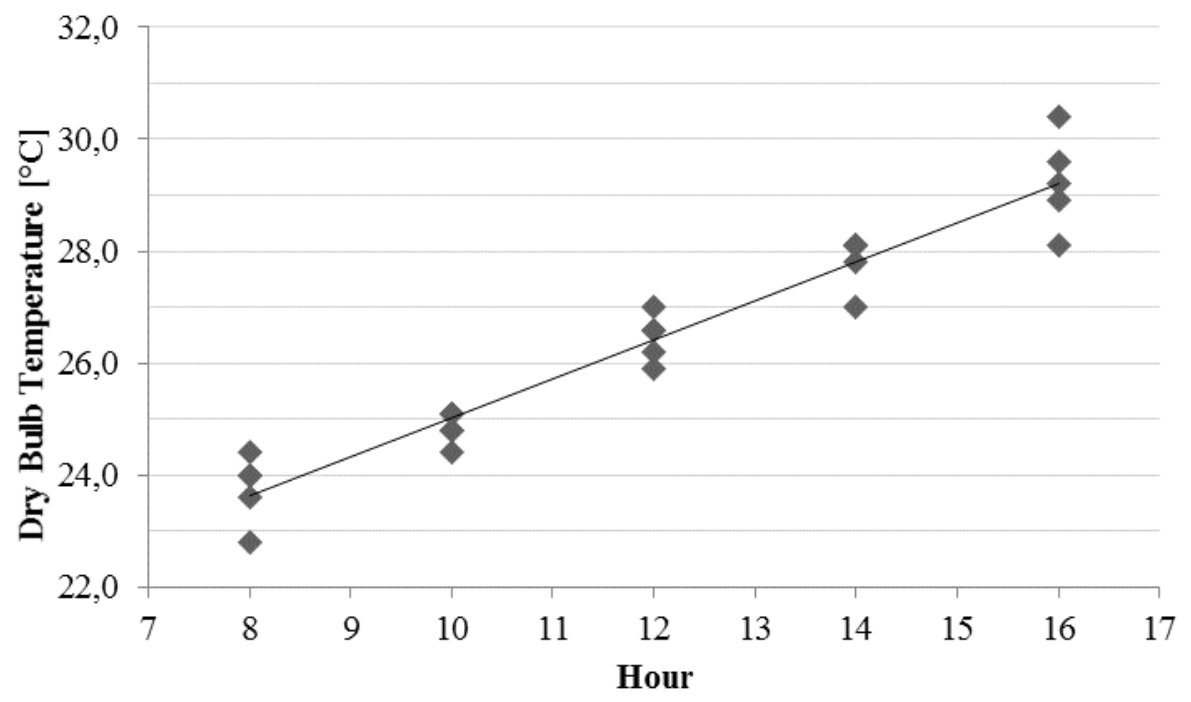

FIGURE 1. Inside air temperature in the climatic chamber during the experimental period.

Despite of the $73.4 \mathrm{~m}^{3} \mathrm{~h}^{-1}$ ventilation rate applied in the environmental chamber (airrenovation of 1.8 times the total volume of $40.6 \mathrm{~m}^{3}$ ); there were changes in ammonia, carbon monoxide and oxygen concentrations within the environment (Table 1)

TABLE 1. Mean, minimum and maximum values and variation coefficient of the environmental variables assessed in the climatic chamber during the experimental period.

\begin{tabular}{ccccc}
\hline Variable $^{1}$ & Mean & Minimum & Maximum & VC \\
\hline $\mathrm{NH}_{3}$ & 75.30 & 55.00 & 100.00 & 15.60 \\
$\mathrm{O}_{2}$ & 20.20 & 19.70 & 20.30 & 0.70 \\
$\mathrm{CO}$ & 2.30 & 0.00 & 6.00 & 126.20 \\
$\mathrm{~T}_{\mathrm{db}}$ & 26.40 & 22.80 & 30.40 & 8.00 \\
$\mathrm{RH}$ & 86.60 & 78.00 & 96.00 & 7.60 \\
$\mathrm{WS}$ & 0.18 & 0.00 & 0.30 & 61.70 \\
$\mathrm{~T}_{\mathrm{L}}$ & 30.50 & 27.20 & 33.50 & 4.90 \\
\hline
\end{tabular}

$\mathrm{NH}_{3}$, ammonia in ppm; $\mathrm{O}_{2}$, oxy gen in $\mathrm{ppm} ; \mathrm{T}_{\mathrm{db}}$, dry bulb temperature in ${ }^{\circ} \mathrm{C} ; \mathrm{RH}$, relative humidity in \%; WS, wind speed in $\mathrm{m}^{-1} . \mathrm{s}^{-1}$; $\mathrm{T}_{\mathrm{L}}$, litter temperature in ${ }^{\circ} \mathrm{C} ; \mathrm{VC}$, variation coefficient in $\%$. 
At the $42^{\text {nd }}$ day, the concentrations of ammonia and oxygen, the litter temperature and relative humidity varied in a linear basis $(\mathrm{p}<0.01)$ according to the dry bulb temperature increasing (Table 2).

TABLE 2. Regression equations for ammonia $\left(\mathrm{NH}_{3}\right)$ and oxygen $\left(\mathrm{O}_{2}\right)$ concentrations, litter temperature $\left(\mathrm{T}_{\mathrm{L}}\right)$ and air relative humidity $(\mathrm{RH})$ inside the climatic chamber according to air increasing temperature $(\mathrm{T})$.

\begin{tabular}{ccccc}
\hline Equations $^{1}$ & Unit & Regression $\mathrm{P}$ & $\mathrm{R}^{2}$ & Figure \\
\hline $\mathrm{NH}_{3}=2.86 \mathrm{~T}_{\mathrm{db}}$ & $\mathrm{ppm}$ & $<0.01$ & 0.98 & 2 \\
$\mathrm{O}_{2}=21.6-0.0565 \mathrm{~T}_{\mathrm{db}}$ & $\mathrm{ppm}$ & $<0.01$ & 0.63 & 3 \\
$\mathrm{~T}_{\mathrm{L}}=18.4+0.458 \mathrm{~T}_{\mathrm{db}}$ & ${ }^{\circ} \mathrm{C}$ & $<0.01$ & 0.38 & 4 \\
$\mathrm{RH}=14.9+2.72 \mathrm{~T}_{\mathrm{db}}$ & $\%$ & $<0.01$ & 0.74 & 5 \\
\hline
\end{tabular}

${ }^{\mathrm{T}} \mathrm{NH}_{3}$, ammonia; $\mathrm{O}_{2}$, oxy gen; $\mathrm{T}_{\mathrm{L}}$, litter temperature ${ }^{\circ} \mathrm{C} ; \mathrm{RH}$, relative humid ity in $\% ; \mathrm{T}_{\mathrm{db}}$, dry bulb temperature in ${ }^{\circ} \mathrm{C}$.

Ammonia concentrations had linear increase with temperature rising $(\mathrm{p}<0.01$; Figure 2$)$, reaching a level of $100 \mathrm{ppm}$. Such high concentration can be explained by this product volatilization enhanced by organic matter fermentation in the broiler litter (SONODA et al., 2012; POTE \& MEISINGER, 2014).

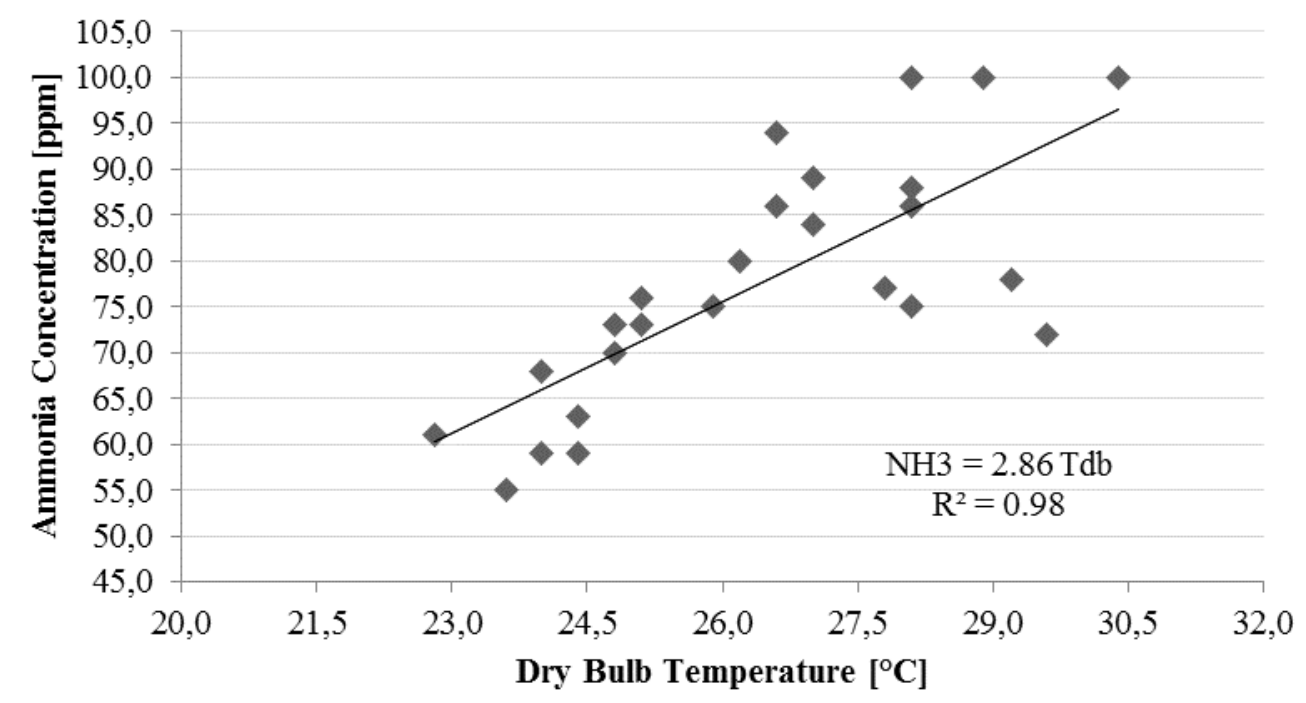

FIGURE 2. Ammonia concentration in response to air temperature elevation in broiler litter after 42-day rearing inside climatic chamber.

Gas concentration in enclosed places varies with certain climatic variables such as wind speed, temperature and relative humidity (CORKERY et al., 2013). Despite the exchange of an amount of 1.8 times the chamber air volume per hour, it might have been possible that air renewal had not been carried out properly, leading to a high ammonia concentration inside the chamber. These observations are common in tunnel-ventilated barns when the design of the cooling system is inappropriate (CARVALHO-CURI et al., 2014).

These findings are similar to those reported by NÄ̈̈S et al. (2007) that observed the increasing in ammonia concentration after a 20-day rearing period with levels greater than $20 \mathrm{ppm}$, which reached $167 \mathrm{ppm}$. LIMA et al. (2011) found out simultaneous increasing in temperature and ammonia concentration as observed on this study (Figure 2).

At the $42^{\text {nd }}$ day, the minimum levels of 55-ppm ammonia (Table 1) were above the maximum level of 10 ppm recommended by COBB-VANTRESS (2013).

The heat wave length and impact on broiler mortality can last for one day or several weeks (VALE et al., 2010). This condition was observed by VALE et al. (2010), associated to ammonia 
concentration increases during extreme heating, what brings about high risks for birds' health and productivity.

The raise of ammonia concentrations observed in this experiment added to a low thermoregulatory capacity of the birds when exposed to high levels of ammonia may represent a synergistic factor that intensify the effect of environment temperature on the high mortality during these heat waves, as reported by VALE et al. (2010).

Oxygen gas concentration decreased linearly while the temperature was risen $(\mathrm{p}<0.01$; Figure 3). This behavior can be attributed to the rising of other gases like ammonia, carbon dioxide and water vapor; this fact comes from the changes on dissociative potential and psychometrics status of these gases (SINGH et al., 2002).

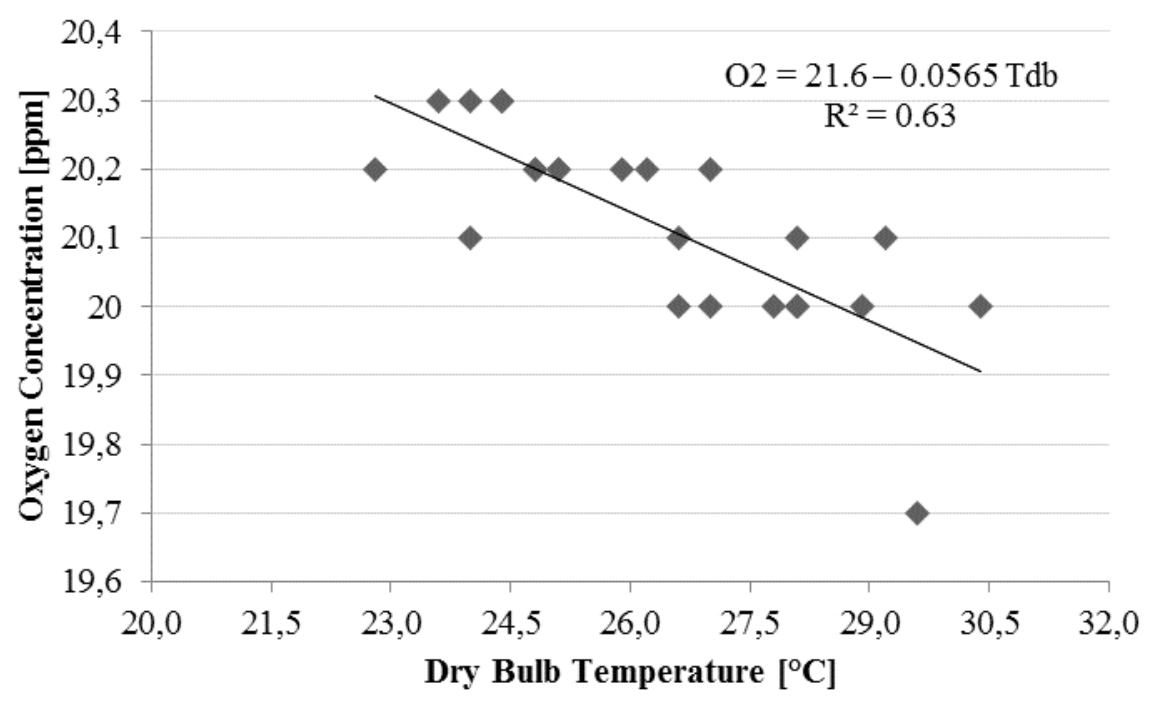

FIGURE 3. Oxygen concentration in response to air temperature elevation in broiler litter after 42 day rearing inside climatic chamber.

The oxygen demand of birds follows cardiac output increases that vary with bird weight and age (HASSANZADEH et al., 2014). Higher environmental temperatures and lower oxygen availability increase lung aeration demands and also cardiac output in order to fulfill physiologic needs of bird tissues (JULIAN, 2005) and thermoregulation (TOYOMIZU et al., 2005).

Besides the temperature rising associated with the ammonia increasing (Figure 2), the lower oxygen availability during the hottest period of the day may justify the higher mortality within heat wave events as already highlighted by VALE et al. (2010) or even give reasonable explanations for the lowest performance of the animals.

Broilers are capable of acclimatizing themselves. However, after being reared under cool conditions for 30 days and being lately exposed to such heat waves (VALE et al., 2010), high mortality rates could be observed due to the lack of acclimation period. The earlier these heat waves occur, the more mortality rate are increased due to a lack of acclimation time (GAUGHAN \& CAWDELL-SMITH, 2015).

The acclimatization period of broilers is an important period for livestock production; if the flock of birds will undergo restraints in oxygen levels, as shown in Figure 3, the death rate may increase because of an increasing number of sudden dea th syndrome.

Sudden death syndrome is a metabolic disease responsible for major losses in broiler production and is linked up with genetic improvement of birds and their cardiovascular status (KARKI et al., 2012; KALMAR et al., 2013). The hottest periods of the year have raised mortality rates from sudden death syndrome (IMAEDA, 2000). 
Stressful situations as extreme heat shock, physiological effects of dry bulb temperature rise (Figure 1) and oxygen concentration reduction in the ambient air (Figure 3) can worsen lung congestion, which is developed by birds during sudden death syndrome (JULIAN, 2005). This status may be aggravated by a collapse in the balance of electrolytes, which would affect bird's ability of supplying these components to vital cardiac outputs in order to survive, added to the incidence of arrhythmias (IMAEDA, 2000).

None of the above-discussed findings provides conclusive answers, since it is a multifactorial condition. Furthermore, most of the deaths could have been due to traumatic and stressful events experienced by birds in an earlier time. Therefore, more physiological studies are needed to clarify how environmental conditions affect the pre-death of birds, based on some subsidies provided in this study to simulations in a controlled environment.

The dry bulb temperature exerted an influence on the litter temperature, showing a linear increase $(\mathrm{p}<0.01)$ between both temperatures (Figure 4$)$.

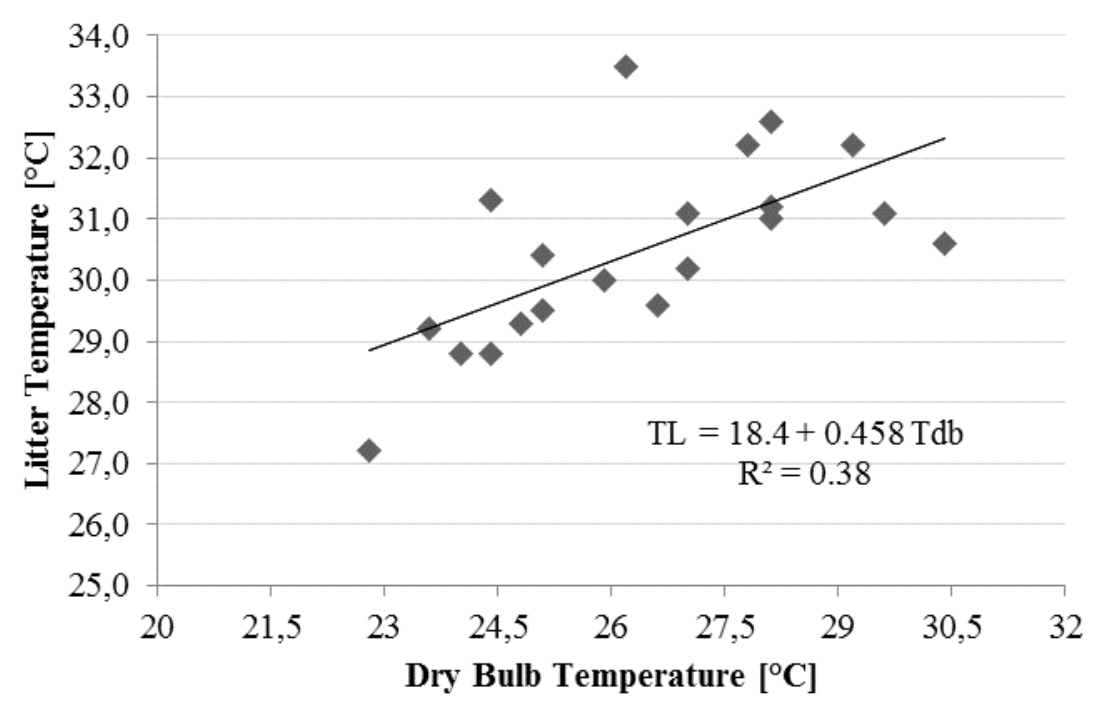

FIGURE 4. Litter temperature in response to air temperature elevation in broilers reared for 42 days inside a climatic chamber.

One of the factors that may increase the mortality of broilers during heat waves is the increase in litter temperature, among other factors previously discussed. Temperatures up to $33.5^{\circ} \mathrm{C}$, as shown in Table 1, reduce the conduction heat exchange between animal and environment, thus reducing the survival of birds.

Table 1 shows the variation in litter temperatures that was from 27.2 to $33.5^{\circ} \mathrm{C}$, which was high enough to prevent heat exchange through birds' feet. A thermographic analysis of the birds' feet showed a variation from 33.4 to $38.7^{\circ} \mathrm{C}$, with an average of $37.2{ }^{\circ} \mathrm{C}$ (YAHAV, 2004), what usually is observed in featherless areas, presenting the highest temperatures. This low temperature gradient between broilers' feet and litter can reduce heat exchanges by conduction made when the air temperature increases.

Besides the direct effect on the birds, high temperatures may also stimulate the activity of thermophilic microorganisms in the litter, increasing thus its temperature.

The humidity rise, observed in Figure 5, may be due to three factors. One is the evaporation from changes in the psychometric traits within the environment (SINGH et al., 2002). Another would be an increased evaporation due to litter temperature growth along with a metabolic heat output by microbial activity (KELLEHER et al., 2002). Finally, there is the metabolic water vapor from birds released by excessive broilers' panting breath during thermal stress conditions (TOYOMIZU et al., 2005). Air renewal inside the chamber was not able to maintain air quality. 
Therefore, an adequate cooling system aside from a low gas concentration inside commercial broiler houses has great importance in broiler poultry.

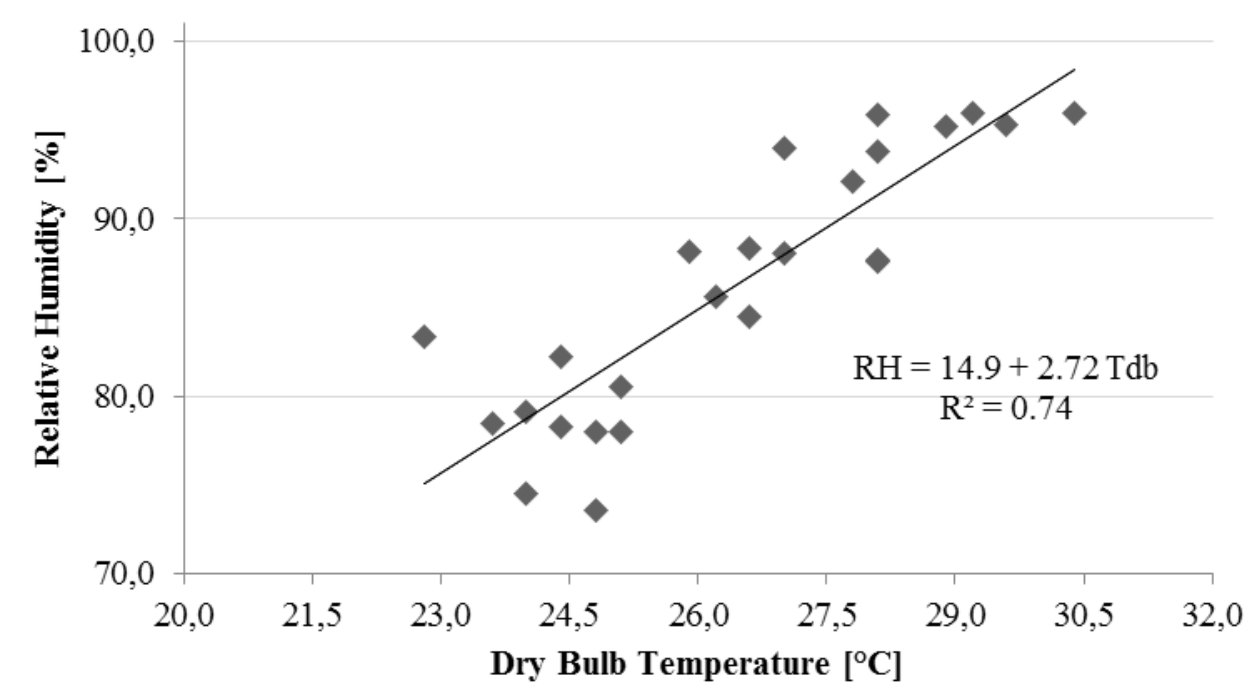

FIGURE 5. Air relative humidity in response to air temperature elevation in broilers reared for 42 days inside a climatic chamber.

Unlike the other environmental parameters, the carbon monoxide showed a different pattern towards the environmental temperature variation, i.e., this gas presented a non-linear pattern. The carbon monoxide concentration was positively correlated to environmental temperature $(0.782$ and $\mathrm{p}<0.010)$, relative humidity (0.688 and $\mathrm{p}<0.01)$ and litter temperature $(0.491$ and $\mathrm{p}=0.028)$; however, this correlation has a non-linear pattern.

Below $26^{\circ} \mathrm{C}$, the carbon monoxide production was null, a fact that occurred in the early hours until midday. Then, these levels increased, and the concentrations reached 1.5, 6 and 4 ppm at 12:00 pm, 2:00 pm and 4:00 pm, respectively.

At high ambient temperatures $\left(27^{\circ} \mathrm{C}\right)$, carbon production was 33 times larger, increasing by 18 times at high relative air humidity $(>88.4 \%)$ and 14 times when litter temperatures got high (> $30.3{ }^{\circ} \mathrm{C}$ ), these data have a $95 \%$ confidence interval.

According to this study finding, the main factor for increasing the carbon monoxide production was the environment temperature that may affect the overall environment of the chamber.

NÄÄS et al. (2007) reported carbon monoxide at concentrations of 40.78 and 105.90 ppm throughout brooding phase, which goes from 0 to 14 days, when this gas is produced by the heating systems. On the other hand, COBB-VANTRESS (2013) stated that the carbon monoxide concentration should be lower than 100 and $50 \mathrm{ppm}$ respectively, as concentration up to $100 \mathrm{ppm}$ reduce the oxygen level in the blood being lethal in higher levels.

Since there was no equipment that could have caused combustion or emitted flammable gases inside the chamber; the presence of carbon monoxide might be attributed to the combustion of litter or organic content by the activity of thermophilic microorganisms (KELLEHER et al, 2002).

The aerobic decomposition of litter organic content occurs during composting when there is a balance between carbon and nitrogen as seen in broiler litter. In addition, the low oxygen concentration can generate an incomplete combustion of organic content, which releases carbon monoxide, which is an intermediate compost of combustion (CEPANKO et al., 2008).

During the early composting process, thermophilic microorganisms induce catalytic reactions that promote the temperature increase in the organic matter of the poultry litter. In the first stage of 
the fermentation, the temperature rises up to $70^{\circ} \mathrm{C}$, which is sufficient to initiate combustion of the material (KELLEHER et al., 2002).

Ammonia stratification occurs within the air column of the poultry house, on a vertical basis, reducing its concentration, since it moves away from poultry litter, which is the location where it was released. The highest concentration of ammonia and carbon dioxide along with the temperature rise can be factors promoting incomplete combustion of organic material leading to reduced availability of oxygen (Figure 3 ) that also favors carbon monoxide production.

As shown in Figures 2 to 5, air degradation dynamics and evolution on days of heat wave, as well as the presence of carbon monoxide, point out the need of setting strategies and alert systems that can assist broiler breeders on making decisions to soften temperature and decrease production of gases inside the facilities.

\section{CONCLUSIONS}

According to the verified environmental conditions inside the chamber, increases of temperature values raised linearly the ammonia concentration and litter temperatures on heat-wave simulation days.

Air oxygen concentration decreased linearly with air temperature increases. The presence of carbon monoxide was observed at temperatures above $27{ }^{\circ} \mathrm{C}$, relative humidity exceeding $88.4 \%$ and litter temperatures higher than $30.3^{\circ} \mathrm{C}$.

\section{ACKNOWLEDGMENTS}

The authors want to thank the Fundação de Amparo à Pesquisa do estado de São Paulo FAPESP (Foundation for Research Support of the state of São Paulo) for this research support and sponsorship.

\section{REFERENCES}

ABIDIN, Z; KHATOON, A. Heat stress in poultry and the beneficial effects of ascorbic acid (vitamin C) supplementation during periods of heat stress. World's Poultry Science Journal, Cambridge, v.69, n.1, p.135-152, 2013.

AMARAL, A.G.; YANAGI JUNIOR, T.; LIMA, R.R.; TEIXEIRA, V.H.; SCHIASSI, L. Effect of the production environment on sexed broilers reared in a commercial house. Arquivo Brasileiro de Medicina Veteriná ria e Zootecnia, Belo Horizonte, v.63, n.3, p.649-658, 2011.

BOIAGO, M.M.; BORBA, H.; SOUZA, P.A.; SCATOLINI, A.M.; FERRARI, F.B.; GIAMPIETRO-GANECO, A. Desempenho de frangos de corte alimentados com dietas contendo diferentes fontes de selênio, zinco e manganês, criados sob condições de estresse térmico. Arquivo Brasileiro de Medicina Veterinária e Zootecnia, Belo Horizonte, v.65, n.1, p.241-247, 2013.

CARVALHO-CURI, T.M.R.; VERCELLINO, R.A.; MASSARI, J.M.; SOUZA, Z.M.; MOURA, D.M. Geoestatística para a avaliação do controle ambiental do sistema de ventilação em instalações comerciais para frangos de corte. Engenharia Agrícola, Jaboticabal, v.34, n.6, p.1062-1074, nov./dez. 2014.

CEPANKO, V.; BUINEVICIUS, K.; PSZCZOŁA, J. Investigation and estimation of exhaust gas emission from fermentable waste combustion. In: INTERNATIONAL CONFERENCE ON ENVIRONMENTAL ENGINEERING, 7., 2008, Vilnius. Anais... Lithuania: European Federation of Biotechnology, 2008. p 266-275.

COBB. Suplemento de crescimento e nutrição para frangos de corte. Massachusetts, 2013. 14 p. Disponível em: <http://www.cobb-vantress.com/docs/default-source/cobb-700-guides/cobb700broiler-performance-and- nutrition-supplement---portuguese.pdf?sfvrsn=0 >. Acesso em: 1 mai. 2014. 
CORKERY, G.; WARD, S.; KENNY, C.; HEMMINGWAY, P. Monitoring environmental parameters in poultry production facilities. In: COMPUTER AIDED PROCESS ENGINEERING, CAPE FORUM, 2013, Graz. Proceedings... Graz: Graz University of Technology, 2013. p.3-12.

GAUGHAN, J.; CAWDELL-SMITH, A.J. Climate change impact on livestock: adaptation and mitigation. Impact of Climate Change on Livestock Production and Reproduction, India, v.1, n.1, p.51-60, 2015.

GUSTAFSSON, G.; NIMMERMARK, S.; JEPPSSON, K.H. Control of emissions from livestock buildings and the impact of aerial environmental on health, welfare and performance of animals $-\mathrm{a}$ review. In: ALAND, A.; BANHAZI, T. Livestock housing: modern management to ensure optimal health and welfare of farm animals. Netherland: Wageningen academic publishers, 2013. p.261270.

HASSANZADEH, M.; BUYSE, J.; TOLOEI, T.; DECUYPERE, E. Ascites syndrome in broiler chickens: a review on the aspect of endogenous and exogenous factors interactions. The Journal of Poultry Science, Soubun, v.51, n.3, p.229-241, 2014.

HENDERSON, B.; GERBER, P.; OPIO, C. Livestock and climate change, challenges and options. Animal Science Reviews, Wallingford, v.1, n.1, p.29-37, 2011.

IMAEDA, N. Influence of the stocking density and rearing season on incidence of sudden death syndrome in broiler chickens. Poultry Science, Oxford, v.79, n.2, p.201-204, 2000.

JULIAN, R.J. Production and growth related disorders and other metabolic diseases of poultry - a review. The Veterinary Journal, Cambridge, v.169, n.3, p.350-369, 2005.

KALMAR, I.D.; VANROMPAY, D.; JANSSENSA, G.P.J. Broiler ascites syndrome: Collateral damage from efficient feed to meat conversion. The Veterinary Journal, Cambrid ge, v.197, n.2, p.169-174, 2013.

KARKI, K.; MANANDHAR, S.; KOIRALA, P. Clinical laboratory outbreak investigation of sudden death synd rome in broiler chicken in Kathmandu valley Nepal 2010. Prime Journal of Microbiology Research, India, v.2, n.1, p.77-79, 2012.

KELLEHER, B.P.; LEAHY, J.J.; HENIHAN, A.M.; O'DWYER, T.F. Advances in poultry litter disposal technology - a review. Bioresource Technology, New York, v.83, n.1, p.27-36, 2002.

KENT, S.T.; MCCLURE, L.A.; ZAITCHIK, B.F.; SMITH, T.T.; GOHLKE, J.M. Heat waves and health outcomes in Alabama (USA): The importance of heat wave definition. Environmental Health Perspectives, Nevada, v.122, n.2, p.151-158, 2014.

LE BOUQUIN, S.; HUNEAU-SALAÜN, A.; HUONNIC, D.; BALAINE, L.; MARTIN, S.; MICHEL, V. Aerial dust concentration in cage-housed, floor-housed, and aviary facilities for laying hens. Poultry Science, Oxford, v.92, n.11, p.2827-2833, 2013.

LIMA, K.A.O.; MOURA, D.J.; CARVALHO, T.M.R.; BUENO, L.G.F.; VERCELLINO, R.A. Ammonia emissions in tunnel- ventilated broiler houses. B razilian Journal of Poultry Science, Campinas, v.13, n.4, p. 265-270, 2011.

NÄÄS, I.A.; MIRAGLIOTTA, M.Y.; BARACHO, M.S.; MOURA, D.J. Ambiência aérea em alojamento de frangos de corte: poeira e gases. Engenharia Agrícola, Jaboticabal, v.27, n.2, p.326335, maio/ago. 2007.

NÄÄS, I.A.; ROMANINI, C.E.B.; S ALGADO, D.D.; LIMA, K.A.O.; VALE, M.M.; LABIGALINI, M.R.; SOUZA, S.R.L.; MENEZES, A.G.; MOURA, D.J. Impact of global warming on beef cattle production cost in Brazil. Scientia Agricola, Piracicaba, v.67, n.1, p.1-8, 2010.

NASCIMENTO, G.R.; PEREIRA, D.F.; NÄAS, I.A.; RODRIGUES, L.H.A. Thermal comfort fuzzy index for broiler chickens. Engenharia Agrícola, Jaboticabal, v.31, n.2, p.219-229, 2011. 
NWAGWU, C.; EDE, P.N.; OKOLI, I.C.; CHUKWUKA, O.K.; OKOLI, G.C.; MOREKI, J.C. Effect of environmental factors and structural dimensions on aerial pollutant gas concentrations in tropical poultry pen in Nigeria. International Journal of Applied Poultry Research, Oxfrod, v.1, n.1., p. 15-20, 2012.

OBA, A.; LOPES, P.C.F.; BOIAGO, M.M.; SILVA, A.M.S.; MONTASSIER, H.J.; SOUZA, P.A. Características produtivas e imunológicas de frangos de corte submetidos a dietas suplementadas com cromo, criados sob diferentes condições de ambiente. Revista Brasileira de Zootecnia, Viçosa, v.41, n.5, p.1186-1192, 2012.

POTE, D.H.; MEISINGER, J.J. Effect of poultry litter application method on ammonia volatilization from a conservation tillage system. Journal of Soil and Water Conservation, Ankeny, v.69, n.1, p.17-25, 2014.

RENAUDEAU, D.; COLLIN, A.; YAHAV, S.; BASILIO, V.; GOURDINE, J.L.; COLLIER, R.J. Adaptation to hot climate and strategies to alleviate heat stress in livestock production. Animal, Cambridge, v.6, n.5, p.707-728, 2012.

SINGH, K.; SINGH, H.; SINGH, S.P.; SAWHNEY, R.L. Numerical calculation of ps ychrometric properties on a calculator. B uilding and Environment, Oxford, v.37, n.4, p.415-419, 2002.

SKUCE, P.J.; MORGANA, E.R.; VAN DIJKA, J.; MITCHELLA, M. Animal health aspects of adaptation to climate change: beating the heat and parasites in a warming Europe. Animal, Cambridge, v.7, n.2, p. 333-345, 2013.

SONODA, L.T.; MOURA, D.J.; BUENO, L.G.F.; CORDEIRO, D.C.; MENDES, A.S. Broiler litter reutilization applying different composting concepts. B razilian Journal of Poultry Science, Campinas, v.14, n.3, p.159-232, 2012.

SOSSIDOU, E.N.; TSIPLAKOU, E.; ZERVAS, G. Options for managing livestock production systems to adapt to climate change. Journal of Earth Science and Engineering, Wisdow, v.4, n.1, p.415-427, 2014.

TOYOMIZU, M.; TOKUDA, M.; MUJAHID, A.; AKIBA, Y. Progressive alteration to core temperature, respiration and blood acid-base in broiler chickens exposed to acute heat stress. The Journal of Poultry Science, Soubun, v.42, p.10-118, 2005.

VALE, M.M.; MOURA, D.J.; NÄÄS, I.A.; PEREIRA, D.F. Characterization of heat waves affecting mortality rates of broilers between 29 days and market age. B razilian Journal of Poultry Science, Campinas, v.12, n.4, p.279-285, 2010.

YAHAV, S. Ammonia affects performance and thermoregulation of male broiler chickens. Animal Research, Les Ulis, v.53, n.4, p.289-293, 2004. 